\title{
A POLYCYSTÁS OVÁRIUM SZINDRÓMÁBAN A TÁPLÁLKOZÁS SZEREPE A CUKORBETEGSÉG KIALAKULÁSÁNAK MEGELŐZÉSÉBEN ÉS A TERÁPIÁS LEHETŐSÉGEK KIEGÉSZÍTÉSÉBEN
}

\author{
Dr. Nagy Károly ${ }^{1}$, Dr. Pósfai Éva ${ }^{2}$ \\ ${ }^{1}$ Bács-Kiskun Megyei Kórnáz, Kecskemét SZTE-ÁOK Oktató Kórháza, Szülészet-nógyógyászati Osztály \\ ${ }^{2}$ Szegedi Tudomány Egyetem- Szent-Györgyi Albert Klinikai Központ
}

\section{SUMMARY}

A polycystás ovárium szindróma (PCOS) a nök körében gyakori, rendkívül komplex endokrin-metabolikus tünetcsoport. A beteg sorsát általában a romló szénhidrát- lipid anyagcserezavarok illetve az ezekhez kapcsolódó, ezek miatt kifejlődő cardiovascularis eltérések határozzák meg. Mára már ismert tény, hogy PCOS miatti hosszan fennálló együttes anyagcsere változások az inzulinrezisztencia fokozódásához, diabetes mellitus kialakulásához vezethetnek. Szerencsére az elmúlt években számos nemzetközi publikáció és ajánlás jelent meg, mely szorgalmazza, hogy a betegség sikeres klinikai kezeléséhez, managementjéhez hozzá kell tartoznia a tudatos preventív szemléletü életmódbeli változás szorgalmazásának, melynek az első vonalbeli terápia részét kell képeznie. Ennek egyik alappillére a megfelelö táplálkozás, diéta, az orvosi táplálkozási terápia ('medical nutrition therapy'). Ezen tanulmány célja az volt, hogy mintegy körképet készítve a nemzetközi irodalomban fellelhetô vezetỏ klinikák publikációi alapján, bemutassa, ma hol áll az oly sokat hangoztatott táplálkozás szerepe a PCOS betegek metabolikus szövödményeinek megelőzésében, a terápiás lehetőségek kiegészítésében, és azt elhelyezze az egyre gyakrabban hangoztatott költség a társadalomra kontra megelözés témakörében.

Kulcsszavak: polycystás ovárium szindróma (PCOS), medical nutrition therapy, insulinresistentia, obesitas

\section{BEVEZETÉS}

A polycystás ovárium szindróma (PCOS) a nők körében egy olyan gyakori, multifaktoriális, összetett tünetegyüttessel bíró kórképnek számít, mely incidenciája az utóbbi évtizedekben fokozatosan növekedett. Ma a felnőtt nők körülbelül 11-26 százalékát érinti a betegség. [1] Etiológiája, eredete azonban máig sem tisztázott.

Habár a betegség tünetei heterogenitásuk miatt széles spektrumot ölelnek fel, mégis a nök többsége elsődlegesen a meddőség, a hyperandrogén tünetek és a rendszertelen ciklusok miatt fordul nőgyógyászhoz. Ugyanakkor mára már ismert és elfogadott tény, hogy ez a szindróma egy olyan komplex nőgyógyászati betegség, amely az egész szervezetre kihathat, így progresszív endokrin-metabolikus kórképként is értelmezhető, amelynek sikeres kezelése integráló orvosi gondozást és preventív szemléletmódot igényel. [2]

A PCOS kezelését nem lehet uniformizálni, minden betegnél egyénre kell szabni, hiszen betegenként eltérỏ tünetegyüttes kombinációval találhatjuk szemben magunkat.

\section{MÓDSZEREK ÉS EREDMÉNYEK}

A tudomány fejlödésének ellenére a betegség hátterében zajló, pontos patomechanizmus még számos pontjában rejteget ismeretlen területeket a klinikusok számára. Ugyanakkor mára már nyilvánvaló, egyre több kutató számol be arról, hogy mind a genetikai, mind a környezeti tényezök is együttesen játszhatnak szerepet a kórkép kialakulásában, alátámasztva a hipotézist miszerint ezen szindróma multifaktoriális eredetủ. A betegség hátterében feltételezhetően inzulinérzékenység-csökkenés (inzulin rezisztencia) és következményes inzulin túltermelödés (hyperinsulinismus) állhat, amely révén fokozódik az 
androgén hormonok aktivitása, okozva ezzel a betegségre jellemzỏ androgén tünetegyüttes megjelenését is.[3, 4] A PubMed, amely a legnépszerübb kereső rendszer az orvos biológiai irodalomban, élettudományi folyóiratok és az online könyvek kapcsán, egyre több publikációt listáz fel a PCOS kapcsán kialakuló inzulinrezisztencia (IR) és következményes hyperinsulinemia témakörében. (1.-2. grafikon) Ennek egyik oka többek között az lehet, hogy egyértelmủen igény van arra, hogy pontos képet kapjunk vajon, mennyi a valós tényleges előfordulása a PCOS betegségben szenvedö nők körében a cukoranyagcsere elváltozásoknak. Hiszen annak ellenére, hogy a szervezet egészét érintheti a szindróma, a beteg sorsát többnyire a romló glükóz- és lipidanyagcsere-zavarok és az ezekhez kapcsolódó, ezek miatt kifejlődő cardiovascularis eltérések határozzák meg. [5] A túlsúlyosság, a kövérség (obesitas), a rossz táplálkozás és a mozgásszegény életmód (a vékony testalkatú nőbetegeknél is) elmélyithetik az endokrin elváltozásokat, amelyek krónikus hormonzavarokhoz csatlakozva elösegithetik a metabolikus (X)-szindróma kialakulását is. Ezért rendkívül fontos, hogy a PCOS miatt a hosszan fennálló együttes anyagcsere változások, amelyek inzulinrezisztenciafokozódáshoz, diabetes mellitushoz kialakulásához vezethetnek, időben a kezdetektől, akár a megjelenésük előtti időszakban is preventiven kerüljenek ellátásra, akár gyógyszeresen és nem gyógyszeres formákban.[1, 6, 7]. (1. ábra)

\section{1. ábra: „Út” a diabetes mellitushoz}

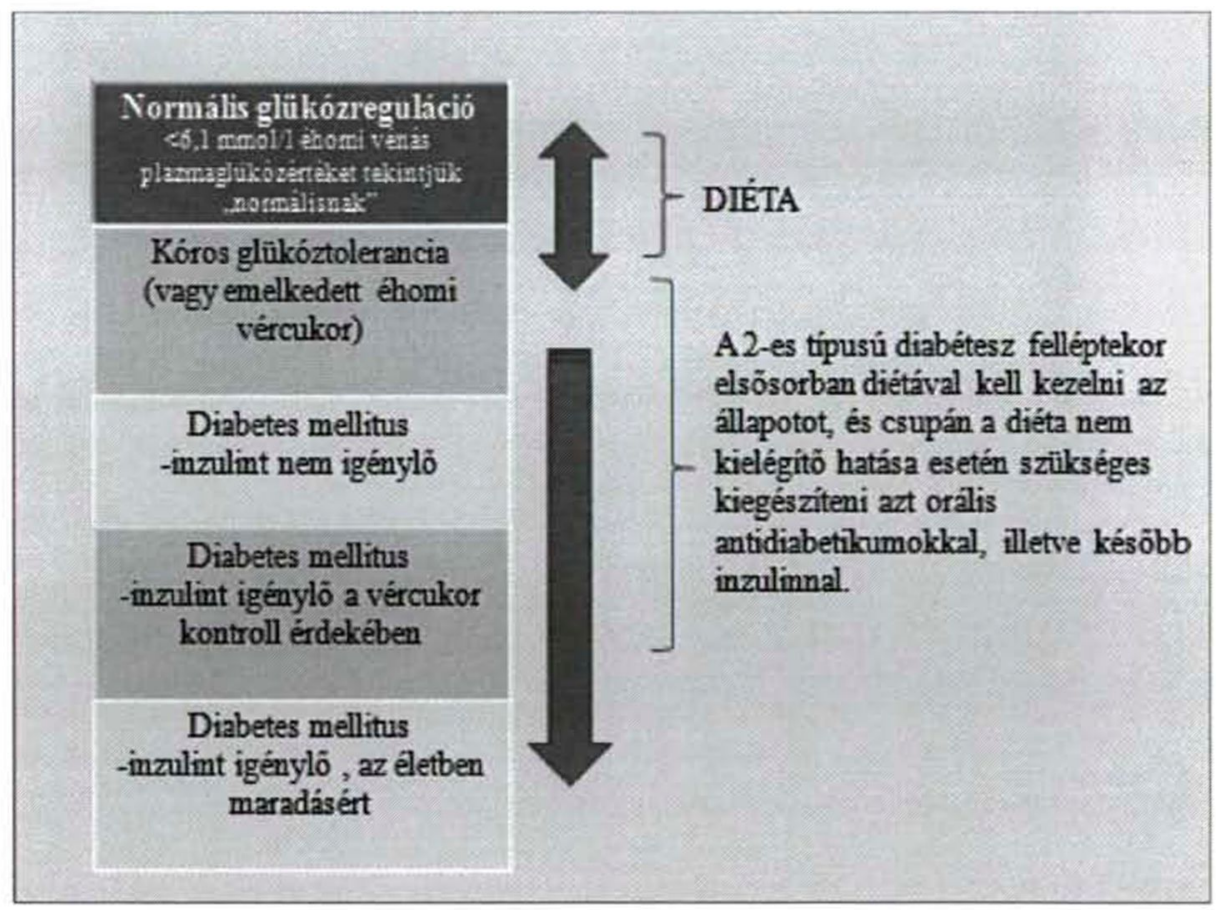


1. ábra: Megjelenő publikációk növekvő számának bemutatása PCOS és hyperinsulinemia témakörben

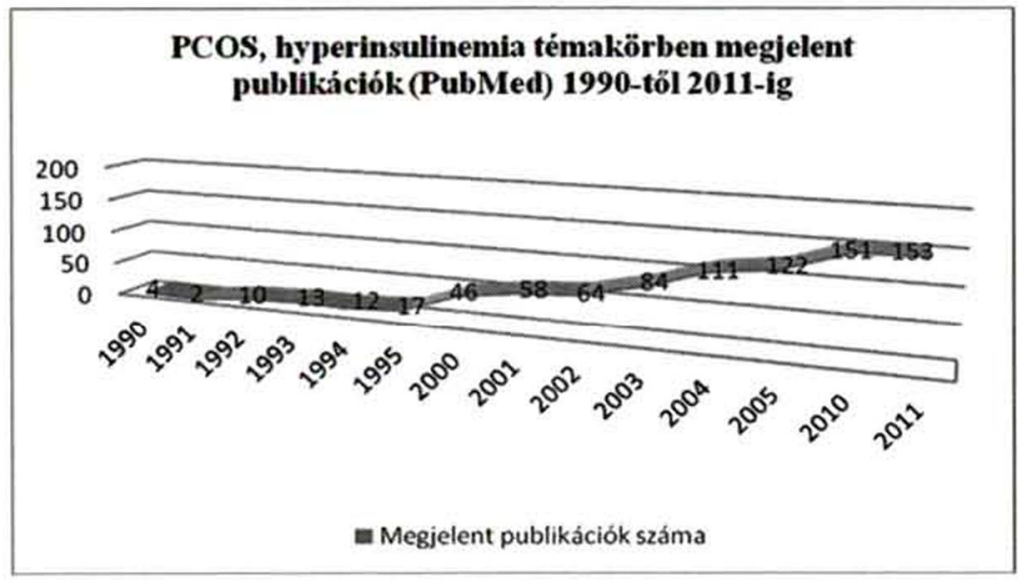

2. ábra: Megjelenő publikációk növekvő számának bemutatása PCOS és az ,insulin resistance", rezisztencia témakörben

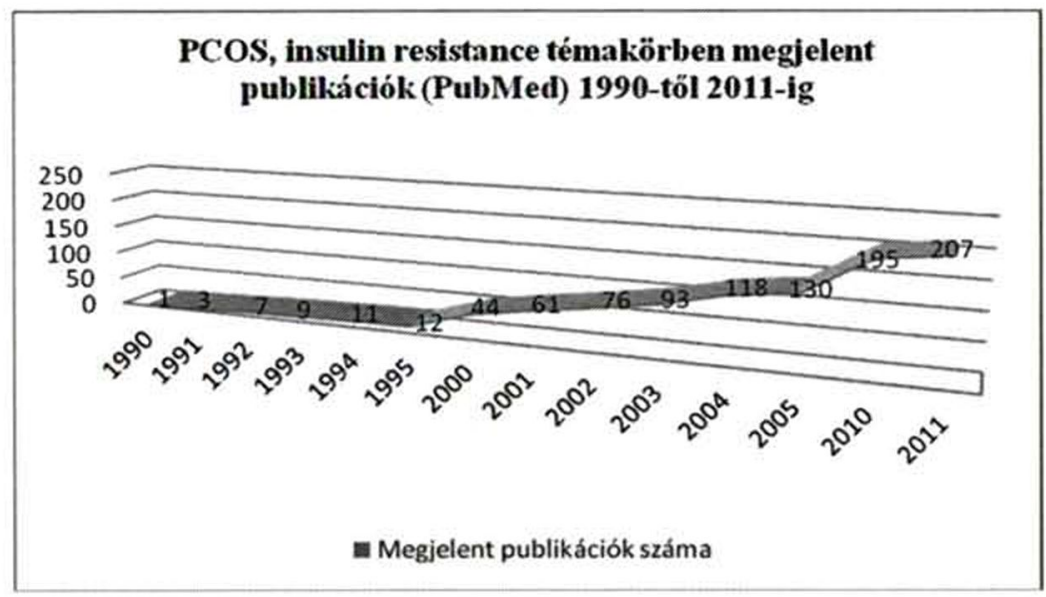

\section{KITEKINTÉS A NEMZETKÖZI SZAKIRODALOMBA}

A portugál nők körében végzett vizsgálatokat Pontes AG. és munkacsoportja. A szerző eredményeik bemutatásában rávilágít arra, hogy a PCOS betegek körében kiemelt szerepe van a glükóz intolerancia és a 2-es típusú diabetes kialakulásának tudatos figyelésére, preventív jellegủ szürések elvégzésére. Fontosnak tartja a glükóz intolerancia teszt rendszeres időközönkénti elvégzését minden PCOS beteg esetén, a fiatal nök körében is. Retrospektiv vizsgálatukban 247 PCOS beteget vontak be. A betegek $64 \%$-a BMI index alapján kövérnek, obesnek számított, akiknél a cukorprofilban való eltérések magasabb arányban fordultak elö. [8] Hasonló eredményekről számolt be Weerakiet S. munkacsoportja is. A csoport az ázsiai nők körében vizsgálta a PCOS és a cukorprofil eltéréseit. 79 nő bevonásával az eredményeik azt mutatták, hogy a glükóz intolerancia sokkal magasabban fordult elő azon nök körében, akik magasabb BMI értékkel rendelkeznek. Feltételezik, hogy a 2-es típusú diabetes mellitus 
kialakulására is fokozottan nagyobb rizikóval rendelkeznek azok a nők, akik obesek és PCOS betegek.[9] Ez az eredmény került megerősitésre a kínai $(20,5 \%)$ és thai $(20,3 \%)$ nők vizsgálata esetében is. [10] Persze felmerül a kérdés, a nem obes PCOS nök körében is nagyobb a rizikó a cukorprofilban való eltérésekre? Ugyanakkor kevés tanulmány lelhető fel, amely a nem obes PCOS nőket hasonlitaná össze az egészséges nők csoportjával. Habár Gambineri A. tanulmányában a fenti kérdésre keresi a választ, mégis 121 PCOS betege körében végzett vizsgálata során nem obes és obes alcsoportok eltéréseit hasonlitotta össze. Az elhízottak körében természetesen súlyosabb inzulin rezisztenciát tapasztalt, mint az enyhén túlsúlyos vagy normál testsúlyhoz képest, amihez hozzáfüzi, hogy magasabb kortizol és androsztendion szint is párosulhat 1-24 ACTH stimuláció hatására. A szerző eredményei alapján kihangsúlyozza a prevenció fontosságát és a megfelelő terápia stratégiájának megválasztását, nemcsak az obes, de a nem obes alcsoport esetében is. Szintén hasonlókat tapasztalt $\underline{\text { Shi } \mathrm{YH}}$. klinikai vizsgálatai alapján, miszerint szignifikánsan nagyobb az inzulinrezisztencia, 2-es típusú diabetes előfordulása enyhén elhízott és obes versus nem obes PCOS csoportban. Azonban kiemeli, hogy a nem obes csoportban való előfordulási gyakoriság sem elhanyagolható. [11] Farshchi H. 2007-ben a Journal of Obstetrics and Gynaecology folyóiratban publikált írása alapján úgy véli, a PCOS erősen összefügg a hasi elhízással és az inzulinrezisztencia kialakulásával. Jelzi annak fontosságát, hogy a PCOS betegek nem mindig kifejezetten túlsúlyosak, de mégis jelen lehet a cukoranyagcsere elváltozás. Publikációjában beszámol arról, hogy a megfelelő táplálkozás és a testmozgás, a jelentős fogyás, ha szükséges, nemcsak csökkenti a betegek cardiometabolikus kockázatát, hanem javíthatja az endokrin és reproduktív funkciókat is. Hangsúlyozza, a makrotápanyagok megfelelö összeválogatásának és bevitelének fontosságát is. [12] Meyer a Human Nutrition Unit, School of Molecular and Microbial Biosciences kutatója a „The optimal diet for women with polycystic ovary syndrome?" címü publikációjában már megfogalmazza a nagy dilemmát, miszerint milyen étrendet is kövessen az a beteg, akinél még csak a lehetősége áll fenn az inzulinrezisztencia vagy a cukorbetegség kialakulásának. Bemutatja 8 hetes klinikai randomizált vizsgálati eredményeit két eltérő típusú étrend alkalmazása esetén, amelyek a magas fehérjemennyiséget HP (30\% fehérje, $40 \%$ szénhidrátot és 30\%-os lipid) versus normál fehérjemennyiséget NP (15\% fehérje, 55\% szénhidrátot és 30\%-os lipid) tartalmaztak. A változásokat a betegek súlya, hormonális és metabolikus profiljának szempontjából elemezte. Habár vizsgálata nem határozta meg egyértelműen az optimális diétát a betegek számára, kutatásai rávilágítottak arra, hogy megfelelő tápanyagbevitellel javítható a hormonális illetve a lipidprofil, és nem csak a betegek testsúlya, a BMI értéke normalizálható. Megfogalmazza, sỏt hiánynak érzi, hogy a legtöbb mai diétás ajánlás a bevitt energia korlátozására irányul, ahelyett hogy olyan diétás ajánlások készülnének, amelyek középpontjában az energiakorlátozás helyett olyan mikro- és makrotápanyagok beépítése állna, amelyek jelentős hatással vannak a vér glükóz- és inzulinszintjére, a lipid anyagcserére. Ezeket egészítené ki alacsony telített zsír- és magas rosttartalmú, alacsony glikémiás indexủ szénhidráttartalmú ételek ajánlásával. (1. táblázat) Sürgetőnek tartja és egyértelmüsíti, hogy további kutatásokra van szükség. Összességében tehát megfogalmazza a 'medical nutrition therapy' kialakításának igényét, nemcsak a már kialakult diabetes esetén, hanem azt megelöző prevenciós fázisban is. [13] 
A POLYCYSTẢS OVÁRIUM SZINDRÓMȦBAN A TÁPLẢLKOZÁS SZEREPE A CUKORBETEGSÉG KIALAKULÁSÁNAK MEGELŐZZÉSÉBEN ÉS A TERÁPIÁS LEHETŐSÉGEK KIEGÉSZITÉSÉBEN • 55

1. táblázat: A föbb élelmiszereink GI idexét bemutató táblázat, a Magyar Diabetes Társaság ajánlása alapján

\begin{tabular}{|c|c|c|}
\hline & GI & Élelmiszer \\
\hline nagyon magas & $90-100 \%$ & $\begin{array}{l}\text { szőlőcukor, malátacukor, méz, cukros } \\
\text { ïdítôitalok, gabona-, kukorica-, rizspehely }\end{array}$ \\
\hline magas & $70-90 \%$ & $\begin{array}{l}\text { (répa- vagy nád)cukor, fehérlisztbỏl készült } \\
\text { pékáruk és fött tészták, szôlő, tejberizs }\end{array}$ \\
\hline közepes & $50-70 \%$ & $\begin{array}{l}\text { kukorica, fött rizs, banán, cukrozatlan } \\
\text { gyümöleslé }\end{array}$ \\
\hline alacsony & $30-50 \%$ & $\begin{array}{l}\text { tej, joghurt, kefir, a legtöbb hazai gyümölcs, } \\
\text { durumbúzából készült spagetti és makaróni }\end{array}$ \\
\hline & $30 \%$ alatt & $\begin{array}{l}\text { bab, lencse, dió, mogyoró, retek, paprika, } \\
\text { paradicsom, fruktóz }\end{array}$ \\
\hline \multicolumn{3}{|c|}{$\begin{array}{l}\text { A GI-tábläzatok egéşséges embereken mért GI-értékeket tartalmaznak, amely a cukorbetegek esetén is irányadó, de a } \\
\text { százalékértékek jelentösen eltérhetnek, és ez a betegség súlyosságától is függ }\end{array}$} \\
\hline \multicolumn{3}{|c|}{$\begin{array}{l}\text { Nōveli a GI értékét minden olyan konyhai technika, amely megsérti a növények sejtfalát, pl. intenziv fózes, turmixolás, } \\
\text { apritás stb. }\end{array}$} \\
\hline
\end{tabular}

\section{Megbeszélés:}

Ahogyan már többször leírtuk, számos nemzetközi publikáció és ajánlás szorgalmazza, hogy a betegség jó klinikai kezeléséhez, managementjéhez hozzá kell tartoznia a tudatos preventív szemléletü súlykontrollnak, a fizikai aktivitásnak, amelyek bizonyitottan csökkenthetik a hyperandrogenizmus és az inzulin szenzitivitást. [3, 6, 8, 14, 15] A még ki nem alakult 2-es típusú diabetes mellitus elött, a glükóz intolerancia kapcsán, a megfelelő diéta és a testmozgás, a tudatos súlykontroll alappillére lehet a kezelésnek, és gyakran elégséges feltétele is. [16] Ugyanakkor a PCOS kezelésében az életmódbeli változtatások szorgalmazása viszonylag újkeletủ gondolat. A PubMed-ben az első általunk talált olyan cikk, amely a PCOS+DIET témakörben született, 1997-re datálható.[17] Ezért sajnos még ma is nagyon sok esetben elmarad a gyógyszeres kezelés megkezdése előtt illetve azzal párhuzamosan a megfelelö diéta és testmozgás beállitása. Ennek egyik oka lehet a hivatalos állásfoglalások alacsony száma a témakörben. Általános felfogás, hogy a diéta lényegében feleljen meg a cukorbetegeknél alkalmazottnak: többször, kevesebb étel fogyasztása, a szénhidrátbevitel csökkentése. Ugyanakkor ma már tudjuk, hogy a sikeres beteggondozáshoz ez nem mindig elég. Habár az általános diéta-testmozgás-súlycsökkentés triászt alkalmazva a betegek jelentős részénél néhány hónap alatt enyhülhetnek a tünetek, mégis fontos kérdés, hogy hogyan diétázzon az a beteg, aki még nem cukorbeteg vagy még nincsenek illetve kialakultak a lipid anyagcsere profiljában is eltérések. Mivel a betegséget egész életen át „karban kell tartani," és törekedni kell a súlyos szövődmények megelőzésére, talán a diéta kifejezés használata itt már nem is célratörő. [18] Habár a diabetológia kapcsán került bevezetésre, a Belgyógyászati Szakmai Kollégium és a Magyar Diabetes Társaság ajánlása alapján, a diéta helyett ma már tanácsosabb orvosi táplálkozási terápiáról (medical nutrition therapy) beszélni, és talán a kifejezés a PCOS betegség esetén is sokkal célratörőbb lehetne.

Szerencsére egyre több klinikus véli úgy, hogy az életmódbeli változtatásoknak az elsö vonalbeli terápia részét kell képeznie olyan PCOS nők esetében is, akik nem küzdenek túlsúllyal. Emellett persze fontos hangsúlyozni a betegek teljes körũ belgyógyászati kivizsgálását is, hiszen mit ér a beteg azzal, ha „diétázik”, de közben a tünetei mögött még egy pajzsmirigy betegség is meghúzódik, ami már első megközelítésben is gyógyszeres kezelést igényelhet.[18, 19]

Rövid kitekintés a PCOS és a diabetes mellitus gazdasági-társadalmi hatásairól 
56 - A POLYCYSTÁS OVÁRIUM SZINDRÓMÁBAN A TÁPLÁLKOZÁS SZEREPE A CUKORBETEGSÉG KIALAKULÁSÁNAK MEGELŐZÉSÉBEN ÉS A TERÁPIÁS LEHETŐSÉGEK KIEGÉSZITTÉSÉBEN

A szakirodalom alapján megállapithatjuk, hogy jelen ismereteink szerint a polycystás ovárium szindrómával diagnosztizált nök $10 \%$-ban alakul ki 2-es típusú diabetes mellitus, mely föleg 40 éves kor környékét érinti. Az International Diabetes Federation legfrissebb 2012. évi adatai alapján bemutatásra került, hogy jelenleg a világon 371 millió cukorbeteg ember él. A diabates prevalanciája WHO standard alapján a világon $8,3 \%$, európában $6,7 \%$ míg Magyarországon $6,12 \%$. Az elmúlt időszakban a cukorbetegek száma hazai viszonylatban (1999. év és a 2007. év között) konstans növekvő tendenciát mutatott. A KSH adati alapján 1999-ben 422063 fö került regisztrálásra cukorbetegséggel, melyből 242588 nő beteg volt. 2007-ben ez a szám már 692927 fö, amelyböl a nő betegek számát 376684 fơre becsülték. Az International Diabetes Federation adatait elemezve az is látható, hogy a betegség kapcsán az egészségügyi kiadások is növekvő tendenciát mutatnak. Magyarországon a 2010.évben egy cukorbetegre fordított egészségügyi kiadás 973 euro/fö volt, ezen ráforditás a 2012. évben ez átlagosan 1272 euróra emelkedett fejenként. A világon a 20 - 79 éves korosztályt érintő (munkaképes korosztály egészét) a cukorbetegséggel összefüggésbe hozható összes halálozást 3,6 millió körülire becsülték, mig Magyarországon ez a szám 7483 fö a 2012. évi adatok szerint. [20] Ugyanakkor külföldön már több olyan tanulmány is készült, melyek alapján elmondható, hogy a legnagyobb társadalmi és gazdasági teher, nem magában a diabetes mellitusban, hanem annak szövődményeiben rejlik. [21-23] Ez a kockázat nem csak a költségekre és nem kívánatos események bekövetkeztére van hatással, hanem a beteg mindennapi életére is. Példaként említhető meg a cukorbetegséggel összefüggő életminőségváltozásról Norris tanulmánya, mely szerint a cukorbetegség megkétszerezi a depresszió kockázatát, és szoros összefüggésben áll a társadalmi szerepek betöltésére való képességgel, a munkavállalással és más egyéb funkcióval is. [24] Az egyik legnagyobb terhet a 2-es típusú diabetes mellitus fontos hosszú távú következményei jelenthetik, melyek között megemlíthetö a szív és agyi erek illetve a végtagi erek érintettsége. Ezek gyakorta vezethetnek szívinfarktushoz, stroke és a diabeteses láb kialakulásához. A betegek életminöségét, munkavállaló képességét szintén nagyban befolyásolhatja a diabeteses vesekárosodás, amely végstádiumban, dializist, müvesekezelést igényelhet, mely egyben nagy költségterheket is hordoz magában. Hasonlóan a diabeteses retinopathiához, ami a becslések szerint, megközelítően a szerzett vakságok 30\%-át teszi ki Európában. Az utóbbi időkben joggal merül fel annak a költségnek az elemzése, mely meghatározó a gyógyitás kontra megelözés társadalmi szintü ráfordításának. A fenti adatokból is jól kirajzolódik, hogy a PCOS és a diabetes mellitus esetén nem csak a kezelés, ha nem annak gazdasági-társadalmi vetületével is szükséges foglalkozni, különös tekintettel a hosszú és rövidtávú szövődmények gyógyitására fordítandó költségelemek szempontjából. A rendelkezésre álló ismereteink alapján elmondható, hogy a megelőzésnek kulcsszerepe van, és nem csak orvosi szempontból, hanem a betegség és annak szövődményei gyógyítására forditott költségek és társadalmi hatások kapcsán is. A megelőzés, a tudatos életmódvezetés (a kialakult betegség esetén is) fontos, még akkor is ha tudjuk, hogy maga a folyama „progresszív”. A számok tükrében arra következtethetünk, hogy megfelelö ellátással, megelőző életmóddal , maguk a szövődmények megjelenése lassítható .

\section{4. ÖSSZEFOGLALÁS}

A diéta-testmozgás-súlycsökkentés triászát alkalmazva, jelentős pozitív irányú változások tapasztalhatóak a betegek cukoranyagcsere folyamataiban. A fö baj az, hogy, bizonyos idő elteltével a betegek visszaállnak régi életmódjukhoz, igy visszaállnak a régi paramétereik is. Ezért talán fontos hangsúlyozni, hogy a diéta-testmozgás-súlycsökkentés triász helyett ma már tanácsosabb 1. a medical nutrition therapy (tudatosan összeválogatott makro- és mikrotápanyagok fogyasztása, antioxidánsok beépitése a rák prevenció végett, hiszen az 
inzulinrezisztencia, a DNS-károsodás és rák növekedett incidenciája bizonyított), 2. a mozgásterápia (amely felöleli a rendszeres, kétnaponkénti mozgást, az inzulin-anyagcsere fiziológiás változásaihoz alkalmazkodás érdekében) és az 3. életmódváltás, „lifestyle modification" triászát szorgalmazni. Hiszen nem elég egy bizonyos idöszakban kezelni a betegséget, hanem egész életen át kordában kell tartani, tudatosan figyelembe venni a nök életének fiziológiás és pszichés kihivásait (terhesség, klimakterium stb) Ezért is olyan fontos egy integráló orvosi gondozást és preventív szemléletmódot átadó betegség-beteg kezelés, oktatás megvalósulása.

\section{IRODALOMJEGYZÉK}

1.Driscoll DA: Polycystic ovary syndrome in adolescence. Ann N Y Acad Sci 2003, 997:49-55.

2.Homburg R: Pregnancy complications in PCOS. Best Pract Res Clin Endocrinol Metab 2006, 20(2):281-292.

3.Arslanian SA, Lewy V, Danadian K, Saad R: Metformin therapy in obese adolescents with polycystic ovary syndrome and impaired glucose tolerance: amelioration of exaggerated adrenal response to adrenocorticotropin with reduction of insulinemia/insulin resistance. J Clin Endocrinol Metab 2002, 87(4):1555-1559.

4.Legro RS, Driscoll D, Strauss JF, 3rd, Fox J, Dunaif A: Evidence for a genetic basis for hyperandrogenemia in polycystic ovary syndrome. Proc Natl Acad Sci U S A 1998, 95(25):1495614960.

5.Mak W, Dokras A: Polycystic ovarian syndrome and the risk of cardiovascular disease and thrombosis. Semin Thromb Hemost 2009, 35(7):613-620.

6.Lim SS, Davies MJ, Norman RJ, Moran LJ: Overweight, obesity and central obesity in women with polycystic ovary syndrome: a systematic review and meta-analysis. Hum Reprod Update 2012.

7.Meyer C, McGrath BP, Teede HJ: Overweight women with polycystic ovary syndrome have evidence of subclinical cardiovascular disease. J Clin Endocrinol Metab 2005, 90(10):5711-5716.

8.Pontes AG, Rehme MF, Micussi MT, Maranhao TM, Pimenta Wde P, Carvalho LR, Pontes A: [The importance of oral glucose tolerance test in diagnosis of glucose intolerance and type 2 diabetes mellitus in women with polycystic ovary syndrome]. Rev Bras Ginecol Obstet 2012, $34(3): 128-132$.

9.Weerakiet S, Srisombut C, Bunnag P, Sangtong S, Chuangsoongnoen N, Rojanasakul A: Prevalence of type 2 diabetes mellitus and impaired glucose tolerance in Asian women with polycystic ovary syndrome. Int J Gynaecol Obstet 2001, 75(2):177-184.

10.Chen X, Yang D, Li L, Feng S, Wang L: Abnormal glucose tolerance in Chinese women with polycystic ovary syndrome. Hum Reprod 2006, 21(8):2027-2032.

11.Shi YH, Zhao DN, Zhao JL, You L, Liu H, Sun M, Chen ZJ: [Characteristics of glucose metabolism in non-obese and obese women with polycystic ovarian syndrome]. Zhonghua Fu Chan Ke Za Zhi 2010, 45(8):575-577.

12.Farshchi H, Rane A, Love A, Kennedy RL: Diet and nutrition in polycystic ovary syndrome (PCOS): pointers for nutritional management. J Obstet Gynaecol 2007, 27(8):762-773.

13.Marsh K, Brand-Miller J: The optimal diet for women with polycystic ovary syndrome? $\mathrm{Br} J$ Nutr 2005, 94(2):154-165.

14.Podrouzek P, Mardesic T: [Polycystic ovary syndrome as a multisystemic endocrinopathy]. Ceska Gynekol 2000, 65(4):260-268.

15.Homburg R: Polycystic ovary syndrome - from gynaecological curiosity to multisystem endocrinopathy. Hum Reprod 1996, 11(1):29-39.

16.Sorensen LB, Soe M, Halkier KH, Stigsby B, Astrup A: Effects of increased dietary protein-tocarbohydrate ratios in women with polycystic ovary syndrome. Am J Clin Nutr 2012, 95(1):39-48.

17.Lefebvre P, Bringer J, Renard E, Boulet F, Clouet S, Jaffiol C: Influences of weight, body fat patterning and nutrition on the management of PCOS. Hum Reprod 1997, 12 Suppl 1:72-81.

18.Norman RJ, Davies MJ, Lord J, Moran LJ: The role of lifestyle modification in polycystic ovary syndrome. Trends Endocrinol Metab 2002, 13(6):251-257. 
19.Celik C, Abali R, Tasdemir N, Guzel S, Yuksel A, Aksu E, Yilmaz M: Is subclinical hypothyroidism contributing dyslipidemia and insulin resistance in women with polycystic ovary syndrome? Gynecol Endocrinol 2012, 28(8):615-618.

20.Roglic G, Unwin N: Mortality attributable to diabetes: estimates for the year 2010. Diabetes Res Clin Pract 2010, 87(1):15-19.

21.Solli O, Jenssen T, Kristiansen IS: Diabetes: cost of illness in Norway. BMC Endocr Disord 2010, 10:15.

22.Economic costs of diabetes in the U.S. In 2007. Diabetes Care 2008, 31(3):596-615.

23.Berend D. K, B.: Egészségmagatartás-modell tesztelése többváltozós technikákkal. Statisztikai Szemle 2012, 90.(5):424-446.

24.Norris SL: Health-related quality of life among adults with diabetes. Curr Diab Rep 2005, 5(2):124-130.

KSH Tájékoztatási Adatbázis

http://statinfo.ksh.hu/Statinfo/haDetails.jsp?query=testquery\&lang=hu

International Diabetes Federation, Diabetes Atlas: epidemiológiai és morbiditási adatok

http://www.diabetesatlas.org/content/epidemiology-and-morbidity 